Check for updates

Cite this: RSC Adv., 2019, 9, 30144

Received 29th June 2019

Accepted 18th September 2019

DOI: $10.1039 / c 9 r a 04913 d$

rsc.li/rsc-advances

\section{Nutritional characteristics of marine fish Sardinella zunasi Bleeker and immunostimulatory activities of its glycoprotein}

\author{
Yu Han, ${ }^{a}$ Huili Hao, ${ }^{a}$ Lihong Yang, ${ }^{\text {ab }}$ Guolian Chen, ${ }^{a}$ Yucong Wen ${ }^{a}$ \\ and Riming Huang (iD) *a
}

Sardinella zunasi Bleeker, an edible and medicinal marine fish, is largely distributed in tropical oceans. However, the chemical composition and nutritional properties of this species have not yet been investigated. In the present study, proximate composition, fatty acids, amino acids, taurine, and minerals of S. zunasi Bleeker were characterized, and the immunostimulatory properties of its glycoprotein were evaluated. The results indicated the presence of crude protein (19.66\%), crude lipid $(6.29 \%)$ and carbohydrate $(0.74 \%)$ in S. zunasi Bleeker; monounsaturated fatty acids and polyunsaturated fatty acids in the fatty acid composition of S. zunasi Bleeker were $25.00 \%$ and $31.01 \%$, respectively; S. zunasi Bleeker was rich in taurine $(219 \mathrm{mg} / 100 \mathrm{~g})$ and essential amino acids $(5.57 \mathrm{~g} / 100 \mathrm{~g})$. In addition, the glycoprotein of S. zunasi consisted of protein and sugars, with a total content of $34.25 \%$ and $16.27 \%$, respectively. The glycoprotein showed significant effects on promoting NO, TNF- $\alpha$ and IL-6 in a dose-dependent manner in RAW264.7 macrophage cells. Thus, these findings provide a scientific basis for the further utilization of glycoprotein from S. zunasi Bleeker.

\section{Introduction}

Fish is a healthy food with numerous benefits to human health. It has been consumed in large quantities not only because it is a source of high nutritional quality protein, but also as a significant reserve of polyunsaturated fatty acids. ${ }^{1}$ Fish muscle is more digestible than other animal protein due to its lower level of connective tissue. Fish fat is one of the few natural food sources of vitamin D and contains important amounts of vitamins A and E. ${ }^{2}$ Fish is a perfect supplement to a high cereal diet because of its high lysine content. ${ }^{3}$ There is plenty of evidence that the consumption of fish reduces the risk of coronary heart disease. ${ }^{4-7}$ Marine fish is a rich source of high-quality protein, lipids, as well as all kinds of vitamins and minerals. It has been reported that the long-chain polyunsaturated (omega-3) fatty acids rich in marine fish, and these polyunsaturated fatty acids can reduce various pathophysiologic abnormalities including anoxic ventricular arrhythmia, atherogenesis, hypertension, blood clotting and cardiovascular disease..$^{\mathbf{8 9}}$

$S$. zunasi Bleeker, an edible and medicinal marine fish, belonging to genus Sardinella, family Clupeidae, is widely

${ }^{a}$ Guangdong Provincial Key Laboratory of Food Quality and Safety, College of Food Science, South China Agricultural University, Guangzhou 510642, China. E-mail: hanyu@stu.scau.edu.cn; hhlhaohuili@stu.scau.edu.cn; guolianchen@scau.edu.cn; vtchong@hotmail.com; huangriming@scau.edu.cn; Tel: +862085283448

${ }^{b}$ Shenzhen Shajing People's Hospital, Guangzhou University of Chinese Medicine, Shenzhen, China.E-mail:13570253038@163.com distributed in the coastal areas of tropical oceans, such as the Philippines, Japan, Korea and China. The species of genus Sardinella are taken as a good source of bioactive components. Previous investigation of genus Sardinella species has exhibited that the chemical or nutritional composition is rich in proteins, lipids (especially polyunsaturated fatty acids), and minerals ${ }^{10-13}$ and significant biological properties such as antioxidant, ${ }^{\mathbf{1 4 , 1 5}}$ antibacterial, ${ }^{\mathbf{1 6}}$ anticancer, ${ }^{17}$ hepatoprotective and nephroprotective, ${ }^{18}$ hypolipidemic, antiobesity and cardioprotective effects. ${ }^{19}$ However, there is still a lack of more data about the chemical or nutritional composition of genus Sardinella, and there is no report about the chemical or nutritional composition of $S$. zunasi Bleeker. Thus, it's necessary to investigate the chemical and nutritional composition of $S$. zunasi Bleeker before any in-depth study.

In order to make more effective utilization of $S$. zunasi Bleeker, the present work aims to determine the chemical and nutritional components including crude protein, crude fat, total carbohydrates, amino acids, taurine, fatty acids and minerals. In addition, the immunomodulatory effect of its glycoprotein on the murine RAW264.7 macrophage cell lines, including evaluating the effects on the proliferation of RAW264.7 cells, phagocytic uptake, the production of nitric oxide (NO), TNF- $\alpha$, and IL- 6 on RAW264.7 cells, was investigated. The results of this work might provide a useful information for further investigation of biological components from $S$. zunasi Bleeker and their utilization. 


\section{Materials and methods}

\subsection{Specimens of fish}

S. zunasi Bleeker was purchased from Zhanjiang, Guangdong Province, China in August 2017. A voucher specimen (no. 20170803) was deposited in Guangdong Provincial Key Laboratory of Food and Safety, South China Agricultural University, China. After collection, fresh fish was packed in plastic bags, preserved in ice and taken immediately to the laboratory, it was preserved in a $-20{ }^{\circ} \mathrm{C}$ refrigerator for about half a month before further treatments. The whole fish were thoroughly washed with running water, cut into pieces and then homogenised in a mincer before the analysis of nutritional characteristics and preparation of crude glycoprotein (H1) and pure glycoprotein (H2). Approximately 20 kilograms of fish was used for the entire study.

\subsection{Standards and reagents}

Standard mixtures of fatty acid methyl ester were purchased from Nu-Chek Prep (Inc., Elysian, MN, USA). All sugars (fructose, rhamnose, arabinose, xylose, mannose, glucose and galactose) were purchased from Aladdin Industrial Corporation (Shanghai, China). Murine RAW264.7 macrophage cells were obtained from Jinan University (Guangzhou, China). Lipopolysaccharides (LPS) and 3-(4,5-dimethyl-2-thiazolyl)-2,5-diphenyl2- $H$-tetrazolium bromide (MTT) were purchased from Sigma Co. (Mo, U.S.A.). Dulbecco Modified Eagle Medium (DMEM), fetal bovine serum (FBS), and penicillin-streptomycin were purchased from Gibco Life Technologies (Grand Island, NY.). Nitric oxide (NO) kit was purchased from Beyotime Biotechnology Co. Ltd. Mouse TNF- $\alpha$, and IL-6 ELISA kits were purchased from NeoBioscience Biotechnology Co. Ltd. DEAECellulose 52 and Sephadex G-200 were purchased from Shanghai Yuanye Bio-Technology Co. Ltd. The other chemicals used in this research were of analytical grade.

\subsection{Proximate composition analysis}

The fish was washed and removed the surface water on the skin before composition analysis. The moisture, crude protein, crude lipid, and ash contents were analysed according to AOAC official methods. ${ }^{20}$ Moisture content was determined using a hot-air oven at $105{ }^{\circ} \mathrm{C}$ for $6 \mathrm{~h}$ until constant weight was reached. Nitrogen content was measured by the Kjeldahl method adapted from where protein content is estimated by multiplying the nitrogen content by 6.25. Crude lipids were determined by Soxhlet extraction with petroleum ether as the solvent. Ash content was measured by heating the fish in a muffle furnace at $550{ }^{\circ} \mathrm{C}$ until the resultant ash was light grey in color. Carbohydrate content was determined using the phenol-sulfuric acid method. ${ }^{21}$

\subsection{Nutritional composition analysis}

2.4.1. Fatty acid profile analysis. The fatty acid profile was obtained using normalization method. $5.0 \mathrm{~g}$ of sample was transferred to $250 \mathrm{~mL}$ radius flask and mixed with $100 \mathrm{mg}$ of pyrogallic acid, $2.0 \mathrm{~mL}$ of $95 \%$ ethanol, $4.0 \mathrm{~mL}$ of deionized water, several zeolites and $10 \mathrm{~mL}$ of $8.3 \mathrm{M} \mathrm{HCl}$. The mixture was hydrolysed in a $75{ }^{\circ} \mathrm{C}$ water bath for $40 \mathrm{~min}$ and shook every $10 \mathrm{~min} .10 \mathrm{~mL}$ of $95 \%$ ethanol was added to the hydrolysate after cooling and then transferred to separating funnel. The radius flask was washed with $50 \mathrm{~mL}$ of diethyl ether and petroleum ether $(1: 1)$ mixed solution and the flushing fluid also transferred to separating funnel. After shaking for $5 \mathrm{~min}$, the ether layer was collected, and then evaporated to dryness. $8 \mathrm{~mL}$ of $2 \%$ sodium hydroxide methanol solution and $7 \mathrm{~mL}$ of $15 \%$ boron trifluoride methanol solution were added to the extraction during heating in an $80^{\circ} \mathrm{C}$ water bath for $5 \mathrm{~min}$, and then cooled to room temperature quickly. $20 \mathrm{~mL}$ of $n$-heptane was added, after 2 min shaking, saturated sodium chloride solution was added. After stratification, $5 \mathrm{~mL}$ of $n$-heptane was taken from the top to a tube and shook with $4 \mathrm{~g}$ of anhydrous sodium sulfate for $1 \mathrm{~min}$, the upper solution was taken for further analysis.

Fatty acids were determined by a gas chromatography $7820 \mathrm{~A}$ (Agilent Technologies, USA), equipped with a flame ionization detector (FID) and a HP88 capillary column (100 m length $\times$ $0.25 \mathrm{~mm}$ ID $\times 0.2 \mu \mathrm{m}$ film thickness). Purified nitrogen was the

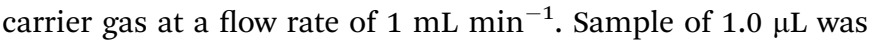
injected with a split ratio of $100: 1$. The injector and detector temperature were $270{ }^{\circ} \mathrm{C}$ and $280{ }^{\circ} \mathrm{C}$, respectively. The column temperature was set at $100{ }^{\circ} \mathrm{C}$ for $13 \mathrm{~min}$, followed by a $10{ }^{\circ} \mathrm{C} \mathrm{min}{ }^{-1}$ heating ramp to $180{ }^{\circ} \mathrm{C}$, which was held for $6 \mathrm{~min}$. Then the temperature was increased to $200{ }^{\circ} \mathrm{C}$ at a rate of $1{ }^{\circ} \mathrm{C} \mathrm{m^{-1 }}$ and held for $20 \mathrm{~min}$. Finally, it was increased to $230{ }^{\circ} \mathrm{C}$ at a rate of $4{ }^{\circ} \mathrm{C} \mathrm{min}{ }^{-1}$ and held for $10.5 \mathrm{~min}$. Fatty acids were identified by comparison of retention time with standard mixtures of fatty acid methyl ester, the composition of fatty acids was expressed in relative percentage of total fatty acids according to their peak areas. ${ }^{22}$

2.4.2. Amino acid profile analysis. Approximately $1 \mathrm{~g}$ sample was put into a vial and hydrolysed with $10 \mathrm{~mL}$ of $6 \mathrm{M}$ hydrochloric acid at $110{ }^{\circ} \mathrm{C}$ under a nitrogen atmosphere for $24 \mathrm{~h}$. The received hydrolysed evaporated to dryness in the flow of warm water. The solid residual was dissolved in $1 \mathrm{~mL}$ of sodium citrate buffers $(0.2 \mathrm{M})$ with $\mathrm{pH} 2.2$ and filtered through a $0.22 \mu \mathrm{m}$ filter before injected into the amino acid analyzer $\mathrm{S}$ 433D (Sykam, Germany). For tryptophan analysis, $1 \mathrm{~g}$ sample was digested with $4 \mathrm{M} \mathrm{NaOH}$ at $110{ }^{\circ} \mathrm{C}$ for $20 \mathrm{~h}$ under nitrogen gas. The hydrolysate was then neutralized to $\mathrm{pH} 7.0$ with $6 \mathrm{M}$ $\mathrm{HCl}$ and added sodium citrate buffers to reach the constant volume and filtered through a $0.22 \mu \mathrm{m}$ filter before injected into an Agilent 1260 (Agilent Technologies, USA) high performance liquid chromatography (HPLC) system. The amino acid results are expressed in $\mathrm{mg}$ of amino acids per $\mathrm{g}$ protein.

2.4.3. Taurine analysis. The taurine content was determined by an Agilent 1260 (Agilent Technologies, USA) HPLC system. $5 \mathrm{~g}$ sample was put into a conical flask, $20 \mathrm{~mL}$ of deionized water was added and sonicated at $40{ }^{\circ} \mathrm{C}$ for $10 \mathrm{~min}$. Then the solution was mixed with $50 \mathrm{~mL}$ of $30 \mathrm{~g} \mathrm{~L}^{-1}$ metaphosphoric acid under ultrasonic treatment for another $10 \mathrm{~min}$. The mixture was transferred to volumetric flask and diluted with distilled water to $100 \mathrm{~mL}$. The sample was centrifuged at 
$5000 \mathrm{rpm}$ for $10 \mathrm{~min}$. The concentrated supernatant was filtered through an ash-free filter and $20 \mu \mathrm{L}$ of them was injected into the HPLC equipped with sodium ion column $(25 \mathrm{~cm} \times 4.6 \mathrm{~mm})$. The excitation and emission wavelengths were $340 \mathrm{~nm}$ and $450 \mathrm{~nm}$, respectively. The mobile phase consisted of trisodium citrate solution which delivered to the column at a flow rate of $0.4 \mathrm{~mL} \mathrm{~min}^{-1}$. The result was expressed in $\mathrm{mg}$ of taurine content per $100 \mathrm{~g}$ fish meat wet weight.

2.4.4. Mineral elements analysis. The mineral elements were measured by inductively coupled plasma optical emission spectrometry 725-ES (Agilent Technologies, USA). $1 \mathrm{~g}$ sample was digested with $15 \mathrm{~mL}$ of $\mathrm{HNO}_{3}$ for 30 min using microwave digestion system. $2 \mathrm{~mL}$ deionized water was added after cooling and continue heating till evaporated to nearly dry. After that, it was diluted with deionized water to $50 \mathrm{~mL}$. The solution was filtered through an ash-free filter before analyzed. A blank digest was also carried out in the same way.

\subsection{Glycoproteins extraction and purification}

The extraction and purification of glycoprotein from $S$. zunasi Bleeker were carried out using the methods described previously. ${ }^{23}$ In brief, the fish was cut into pieces and ground up in a blender, then extracted twice by using a hot water method with the conditions of liquid/solid ratio of $20: 1$, temperature of $95{ }^{\circ} \mathrm{C}$ and extraction time of $2 \mathrm{~h}$. The combined aqueous extracts were concentrated in a rotary evaporator under reduced pressure at $50{ }^{\circ} \mathrm{C}$ and then filtered. The free proteins in the extracts were removed by using Sevag reagent (chloroform $/ n$ butanol, v/v $=4: 1$ ). The deproteinized solution was precipitated with addition of ethanol to reach a final ethanol concentration of $75 \%$ at $4{ }^{\circ} \mathrm{C}$ for $24 \mathrm{~h}$. Following centrifugation at $12000 \mathrm{rpm}$ for $15 \mathrm{~min}$, the precipitates were washed sequentially with anhydrous ethanol and acetone, and then dialyzed against deionized water for 2 days and lyophilized as crude glycoprotein (H1).

The crude glycoprotein (H1) was dissolved in distilled water and separated by a DEAE-Cellulose 52 column $(2.0 \mathrm{~cm} \times 40$ $\mathrm{cm})$. The column was eluted with distilled water and a stepwise $\mathrm{NaCl}$ gradient (0-1 M). One independent elution peak of the glycoprotein was obtained by phenol-sulfuric acid method at $490 \mathrm{~nm}$. The glycoprotein fraction was collected, dialyzed, concentrated, and further loaded into Sephadex G-200 column $(1.8 \mathrm{~cm} \times 50 \mathrm{~cm})$ with distilled water at a flow rate of 0.5 $\mathrm{mL} \min ^{-1}$. One independent elution peak of the glycoprotein was obtained by phenol-sulfuric acid method at $490 \mathrm{~nm}$. One main fraction was finally obtained, dialyzed, lyophilized and denoted as $\mathrm{H} 2$.

\subsection{Physicochemical characterization of $\mathbf{H 2}$}

2.6.1. Molecular weight analysis. The molecular weights of $\mathrm{H} 2$ was measured by a high-performance gel-permeation chromatography (HPGPC) on a Waters 1525 HPLC system fitted with two connecting columns, TSK G-5000PWXL $(7.8 \mathrm{~mm} \times 300 \mathrm{~mm})$ and TSK G-3000PWXL $(7.8 \mathrm{~mm} \times 300$ $\mathrm{mm}$ ), and monitored with a Waters 2414 differential refractive index detector. $10 \mu \mathrm{L}$ of $2 \mathrm{mg} \mathrm{mL}^{-1} \mathrm{H} 2$ was injected to the system and eluted with $0.02 \mathrm{M} \mathrm{KH}_{2} \mathrm{PO}_{4}$ at a flow rate of $0.6 \mathrm{~mL} \min ^{-1}$ at $35{ }^{\circ} \mathrm{C}$. The GPC system was calibrated before sample analysis with dextran standards (MW: 668 kDa, $410 \mathrm{kDa}, 273 \mathrm{kDa}, 148 \mathrm{kDa}, 48.6 \mathrm{kDa}, 23.8$ $\mathrm{kDa}, 11.6 \mathrm{kDa}$, and $5.2 \mathrm{kDa})$.

2.6.2. Monosaccharide analysis. The monosaccharide composition was analyzed by a Trace 1310 gas chromatography (GC) coupled with TSQ 8000 Evo mass spectrometry (MS) (Thermo Fisher Scientific, USA). $10 \mathrm{mg}$ sample was hydrolyzed with $4 \mathrm{~mL}$ of $2 \mathrm{M}$ trifluoroacetic acid (TFA) at $130{ }^{\circ} \mathrm{C}$ in a sealed glass tube for $4 \mathrm{~h} .2 \mathrm{~mL}$ of methanol was used to remove excess TFA in a rotary evaporator under reduced pressure at $50{ }^{\circ} \mathrm{C}$ for three times after completing the hydrolysis. Then $10 \mathrm{mg}$ of hydroxylamine hydrochloride and $2 \mathrm{~mL}$ of pyridine were added to the tube and incubated at $90{ }^{\circ} \mathrm{C}$ for $40 \mathrm{~min}$. After that, $2 \mathrm{~mL}$ of acetic anhydride was added and incubated at $90{ }^{\circ} \mathrm{C}$ for another $40 \mathrm{~min} .2 \mathrm{~mL}$ deionized water was added to eliminate the reaction. Acetylated derivatives were extracted with $3 \mathrm{~mL}$ chloroform for three times, and chloroform fractions were collected and concentrated at $40{ }^{\circ} \mathrm{C}$. The residuum was dissolved with chloroform and $1 \mu \mathrm{L}$ of it was injected to the system. Analytes were separated in the GC with a TG-5MS GC column (60 $\mathrm{m}$ length $\times 0.25 \mathrm{~mm}$ ID $\times 0.5 \mu \mathrm{m}$ film thickness) at 1.2 $\mathrm{mL} \min ^{-1}$ helium flow and detected by MS using full scan mode $(m / z 50-550)$. The injector and detector temperature were $230{ }^{\circ} \mathrm{C}$ and $280{ }^{\circ} \mathrm{C}$, respectively. The column temperature was programmed as follows: $110{ }^{\circ} \mathrm{C}$ for $1 \mathrm{~min}$; a $15{ }^{\circ} \mathrm{C} \min ^{-1}$ heating ramp to $180{ }^{\circ} \mathrm{C}$, which was held for $1 \mathrm{~min}$; a heating ramp to $280^{\circ} \mathrm{C}$ at a rate of $2.5^{\circ} \mathrm{C} \mathrm{min}{ }^{-1}$ and held for $10 \mathrm{~min}$. The standard monosaccharides were prepared and subjected to the system in the same way.

2.6.3. FTIR spectroscopy. The FT-IR spectrum for $\mathrm{H} 2$ was determined using a Fourier Transform Infrared (FT-IR) in the spectrophotometer with a frequency range of 4000$400 \mathrm{~cm}^{-1}$. H2 (1-2 mg) was adequately dried and ground with spectroscopic grade $\mathrm{KBr}$ powder $(100 \mathrm{mg})$, then pressed into a $1 \mathrm{~mm}$ pellet for FT-IR measurement using a VERTEX 70 FT-IR infrared spectrometer (Bruker, Germany).

\subsection{Immunomodulatory activity of $\mathbf{H} 2$}

2.7.1. Cell culture. Murine RAW264.7 macrophage cells were cultured in DMEM medium supplemented with $10 \%(\mathrm{v} / \mathrm{v})$ FBS and $1 \%(\mathrm{v} / \mathrm{v})$ penicillin-streptomycin at $37{ }^{\circ} \mathrm{C}$ in a humidified $5 \% \mathrm{CO}_{2}$ atmosphere.

2.7.2. Cell viability assay. Cell viability was determined by MTT method. ${ }^{24,25}$ RAW264.7 macrophage cells were seeded in 96-well plates at a density of $3 \times 10^{4}$ cells $\mathrm{mL}^{-1}$ in $100 \mu \mathrm{L}$ culture medium at an incubator $\left(37{ }^{\circ} \mathrm{C}, 5 \% \mathrm{CO}_{2}\right)$. After incubation for $24 \mathrm{~h}$, the cells were treated with $100 \mu \mathrm{L}$ of different concentrations of $\mathrm{H} 2(10,20,40,60,80,100,120$ and $140 \mu \mathrm{g} \mathrm{mL}^{-1}$ ) and incubated for another $24 \mathrm{~h}$. In addition, equivalent volume of culture medium was used as the blank control. After treatment, $10 \mu \mathrm{L}$ of MTT at $5 \mathrm{mg} \mathrm{mL}^{-1}$ was added to each well and further incubation for $4 \mathrm{~h}$. At last, cell supernatant was moved and $100 \mu \mathrm{L}$ of dimethyl 
sulfoxide (DMSO) were added. After shaking for $10 \mathrm{~min}$, absorbance then was recorded at $540 \mathrm{~nm}$ wavelength using an automated microplate reader SpectraMax i3x (Molecular Devices, Austria). The cell survival ratio was expressed as a percentage of the control using the following formula:

$$
\text { Cell viability }(\%)=\left(A_{2}-A_{0}\right) /\left(A_{1}-A_{0}\right) \times 100
$$

where $A_{1}$ was the absorbance of the control group; $A_{2}$ was the absorbance of the test samples group; $A_{0}$ was the absorbance of group treated with only culture medium.

2.7.3. Phagocytic assay. Effects of $\mathrm{H} 2$ on the phagocytosis of RAW264.7 cells were measured by neutral red uptake method. ${ }^{26}$ RAW264.7 macrophage cells were seeded in 96well plates at a density of $3 \times 10^{4}$ cells $\mathrm{mL}^{-1}$ in $100 \mu \mathrm{L}$ culture medium at an incubator $\left(37^{\circ} \mathrm{C}, 5 \% \mathrm{CO}_{2}\right)$. After cells were cultured with $100 \mu \mathrm{L}$ of various concentrations $(10,20$, $40,60,80,100$ and $\left.120 \mu \mathrm{g} \mathrm{mL}^{-1}\right)$ of $\mathrm{H} 2$ or LPS $\left(2 \mu \mathrm{g} \mathrm{mL}^{-1}\right)$ for $24 \mathrm{~h}$, the culture medium was removed and $100 \mu \mathrm{L}$ per well $0.1 \%$ neutral red solution was added. The plates were incubated for $1 \mathrm{~h}$ and cells were washed with $0.01 \mathrm{M}$ PBS ( $\mathrm{pH}$ 7.4) three times to remove excess neutral red. $100 \mu \mathrm{L}$ per well lysis solutions (ethanol/acetic acid $1: 1$ ) were added, and then the cells were lysis for $30 \mathrm{~min}$ at room temperature. The absorbance was determined at $540 \mathrm{~nm}$ by microplate reader (Molecular Devices, Austria). The phagocytic rate was calculated by the following formula:

$$
\text { Phagocytosis rate }(\%)=\left(A_{2}-A_{0}\right) /\left(A_{1}-A_{0}\right) \times 100
$$

where $A_{1}$ was the absorbance of the control group; $A_{2}$ was the absorbance of the test samples group; $A_{0}$ was the absorbance of group treated with only culture medium.

2.7.4. Nitric oxide (NO) assay. NO levels in the cultured supernatants were measured by the Griess regent as described previously. ${ }^{27}$ RAW264.7 macrophage cells were seeded in 24-well plates at a density of $5 \times 10^{5}$ cells $\mathrm{mL}^{-1}$ in $500 \mu \mathrm{L}$ culture medium at an incubator $\left(37{ }^{\circ} \mathrm{C}, 5 \% \mathrm{CO}_{2}\right)$. After incubation for $18 \mathrm{~h}$, the cells were treated with $1000 \mu \mathrm{L}$ of LPS $\left(2 \mu \mathrm{g} \mathrm{mL}^{-1}\right)$, a series of concentrations of $\mathrm{H} 2(5,10,20$ and $60 \mu \mathrm{g} \mathrm{mL} \mathrm{m}^{-1}$ ), respectively, and incubated for $24 \mathrm{~h}$. Then Griess reagent $(50 \mu \mathrm{L})$ was added to $50 \mu \mathrm{L}$ of collected supernatant and absorbance at $540 \mathrm{~nm}$ wavelength was recorded. Griess method is based on the determination of nitrite ions obtained by quantitative reduction (greater than $90 \%$ ) of nitrate ions present in the sample. Therefore, the sum of nitrite and nitrate ion concentrations is measured. Nitrate concentration is deduced by subtracting the original nitrite from sample of the total nitrite concentration (sum of these $\mathrm{NO}_{2}$ with reduced $\mathrm{NO}_{3}$ ). A standard solution of $\mathrm{NaNO}_{3}$ was used for calibration.

2.7.5. TNF- $\alpha$ and IL-6 determination. RAW264.7 macrophage cells were incubated in 24-well plates at a density of 5 $\times 10^{5}$ cells $\mathrm{mL}^{-1}$ in $500 \mu \mathrm{L}$ culture medium at an incubator $\left(37{ }^{\circ} \mathrm{C}, 5 \% \mathrm{CO}_{2}\right)$. After incubation for $18 \mathrm{~h}$, the cells were treated with $1000 \mu \mathrm{L}$ of a series of concentrations of $\mathrm{H} 2$ (5, 10,20 and $60 \mu \mathrm{g} \mathrm{mL}^{-1}$ ), respectively, and incubated for $24 \mathrm{~h}$.
Cells with culture medium were used as a negative control and LPS $\left(2 \mu \mathrm{g} \mathrm{mL}^{-1}\right)$ was used as a positive control. Cytokines IL- 6 and TNF- $\alpha$ levels were assessed using an immune enzymatic assay (ELISA) kit according to the manufacturer instructions. Samples were analyzed in triplicate and optical density was determined at $450 \mathrm{~nm}$.

\subsection{Statistical analysis}

Data were expressed as mean $\pm \mathrm{SD}$, at least 3 independent experiments for each sample except fatty acids analysis of $S$. zunasi Bleeker and composition analysis and amino acid composition of $\mathrm{H} 2$. Statistical significance was calculated by one-way analysis of variance ANOVA followed by Turkey's test to determine the difference between groups (GraphPad Prism 5.0). Values of $P<0.05$ were considered as statistically significant.

\section{Results and discussion}

\subsection{Proximate composition}

The proximate composition of $S$. zunasi Bleeker is presented in Table 1 . Moisture $(68.75 \% \pm 0.79 \%)$ was the most abundant component in $S$. zunasi Bleeker, similar to Pomatomus saltatrix $(70.87 \% \pm 0.59 \%)$ and Engraulis encrasicolus $(66.95 \% \pm$ $0.64 \%) .^{28}$ The protein content ${ }^{29}$ ranged from $17 \mathrm{~g} / 100 \mathrm{~g}$ to $20 \mathrm{~g} /$ $100 \mathrm{~g}$ for freshwater and $18 \mathrm{~g} / 100 \mathrm{~g}$ to $22 \mathrm{~g} / 100 \mathrm{~g}$ for marine fish. Crude protein content of $S$. zunasi Bleeker was $19.66 \% \pm 0.15 \%$, higher than that of Mullus barbatus (14.54\% $\pm 0.00 \%)$, Pomatomus saltatrix $(15.24 \% \pm 0.55 \%)$ and Scorpaena porcus $(16.91 \%$ $\pm 0.04 \%) .{ }^{28}$ Fishes were often classified as lean fish (lipid content $<5 \%)$, medium fat fish $(5-10 \%)$, and fatty fish $(>10 \%)$ on the basis of their fat content. ${ }^{30}$ Based on this classification, $S$. zunasi Bleeker was medium fat fish with $6.29 \% \pm 0.74 \%$ lipid content, was similar to values reported in muscle of other fish species, such as sardines and mackerel. ${ }^{1}$ The ash content $(6.16 \% \pm 0.28 \%)$ of $S$. zunasi Bleeker was much higher than those of Pampus argenteus $(2.25 \% \pm 0.62 \%)$ and Harpadon nehereus $(0.93 \% \pm 0.11 \%) .{ }^{31}$ The major carbohydrate composition in fish muscle is glycogen that is a polymer of glucose. A typical muscle in a live fish may contain between 0.1 and $1 \%$ glycogen..$^{32}$ In our study, we found carbohydrate content of $S$. zunasi Bleeker was $0.74 \% \pm 0.01 \%$, which agreed with the value reported in literature. ${ }^{32}$

Table 1 The proximate composition of S. zunasi Bleeker (mean \pm SD, $n=3)$

\begin{tabular}{lr}
\hline Proximate composition & \multicolumn{1}{c}{ Content $^{a}(\%)$} \\
\hline Moisture & $68.75 \pm 0.79$ \\
Crude protein & $19.66 \pm 0.15$ \\
Crude lipid & $6.29 \pm 0.74$ \\
Ash & $6.16 \pm 0.28$ \\
Carbohydrate & $0.74 \pm 0.01$ \\
${ }^{a}$ Values expressed as wet weight. &
\end{tabular}


Table 2 The fatty acid composition of S. zunasi Bleeker

\begin{tabular}{|c|c|}
\hline Fatty acids & Content $^{a}(\%)$ \\
\hline C12:0 & 0.14 \\
\hline C13:0 & 0.16 \\
\hline C14:0 & 8.60 \\
\hline C14:1 & 0.11 \\
\hline C15:0 & 0.91 \\
\hline C16:0 & 21.8 \\
\hline C16:1 & 7.60 \\
\hline C17:0 & 1.40 \\
\hline C17:1 & 1.40 \\
\hline C18:0 & 8.50 \\
\hline C18:1 & 12.40 \\
\hline C18:2 & 3.10 \\
\hline C18:3 & 1.30 \\
\hline C18:4 & 0.75 \\
\hline C20:0 & 1.10 \\
\hline C20:1 & 1.50 \\
\hline C20:2 & 0.15 \\
\hline C20:3 & 0.21 \\
\hline C20:4 (ARA) & 2.70 \\
\hline C20:5 (EPA) & 9.60 \\
\hline $\mathrm{C} 21: 0$ & 0.32 \\
\hline C22:0 & 0.50 \\
\hline C22:1 & 0.89 \\
\hline C22:5 (EPA) & 2.50 \\
\hline C22:6 (DHA) & 10.70 \\
\hline C24:0 & 0.24 \\
\hline C24:1 & 1.10 \\
\hline $\mathrm{SFA}^{b}$ & 43.67 \\
\hline MUFA $^{c}$ & 25.00 \\
\hline PUFA $^{d}$ & 31.01 \\
\hline
\end{tabular}

${ }^{a}$ Values expressed as wet weight. ${ }^{b}$ SFA: saturated fatty acids. ${ }^{c}$ MUFA: monounsaturated fatty acids. ${ }^{d}$ PUFA: polyunsaturated fatty acids.

\subsection{Nutritional composition analysis}

3.2.1. Fatty acid content. The fatty acid composition of $S$. zunasi Bleeker is presented in Table 2 . Twenty-seven fatty acids composed of C12:0 to C24:1, were identified. Fatty acids were generally divided into three categories: saturated fatty acids (SFA), monounsaturated fatty acids (MUFA) and polyunsaturated fatty acids (PUFA). These three fatty acids were found in 43.67, 25.00 and 31.01 percent of $S$. zunasi Bleeker, respectively. In recent decades, the WHO has recommended reduced consumption of saturated fatty acids based on their effects in increasing low density lipoprotein cholesterol (LDL-c) and risks of heart diseases. ${ }^{33}$ The marine fish $S$. zunasi Bleeker contained more UFA than SFA, the PUFA/SFA ratio (0.71) was higher than 0.45 that is an essential value of high nutritional food. Besides, EPA (Eicosapntemacnioc Acid) and DHA (Docosahexaenoic Acid) were important source of n-3 PUFA, together accounting for $20.30 \%$ of total fatty acids in $S$. zunasi Bleeker, higher than those of white herring, small yellow croaker and spotted maigre, ${ }^{22}$ indicated $S$. zunasi Bleeker was a healthy source of fatty acids.

3.2.2. Amino acids content. The content of amino acids (AAs) and the proportion of amino acid components determined the nutritional value of protein in food. Some amino acids, such as cysteine (or sulphur-containing amino acid), tyrosine (or aromatic amino acids), histidine and arginine are required by infants and growing children. ${ }^{34}$ Deficiency in these amino acids may hinder healing recovery process. ${ }^{35}$ AAs have been traditionally classified as nutritionally essential amino acids (EAA), nonessential amino acids (NEAA) or conditionally essential amino acids (CEAA). ${ }^{36}$ The amino acid profile of $S$. zunasi Bleeker is shown in Table 3. Seventeen amino acids were identified. All of the essential amino acids were found to be present in $S$. zunasi Bleeker, accounting for $36.41 \%$ of the total amino acid. The highest content was glutamic acid at $2.41 \mathrm{~g} / 100 \mathrm{~g}$, which agreed with the reported data of four commonly consumed marine fishes. ${ }^{37}$ Lysine $(8.50 \%)$, leucine $(7.39 \%)$ and valine $(4.58 \%)$ were the three most abundant essential amino acids, while glutamine and glutamic acid (15.75\%), aspartic acid $(9.48 \%)$ and glycine $(8.56 \%)$ constituted the three most abundant nonessential amino acids in $S$. zunasi Bleeker.

3.2.3. Taurine content. Taurine, a derivative of cysteine, lacks a carboxyl group in structure and is not strictly an amino acid, but contains a sulfonic acid group, so it is called sulfonic acid. The content of taurine was measured as $219 \mathrm{mg} / 100 \mathrm{~g}$ (wet weight) in $S$. zunasi Bleeker, which was higher than that of other marine species, such as mackerel (78 mg/100 g) and albacore tuna $(40 \mathrm{mg} / 100 \mathrm{~g}){ }^{38}$ Beneficial effects of taurine on cardiovascular risk factors have been proposed, ${ }^{39-42}$ and both a reduction in body weight, ${ }^{\mathbf{4}}$ beneficial effects on blood lipids, ${ }^{\mathbf{4 4}}$ antiatherosclerotic, and anti-inflammatory effects have been observed. ${ }^{40}$ The anti-obesity effects of taurine may partly be due to suppression of inflammation in adipose tissue. ${ }^{45}$ Taurine supplementation has been found to increase adiponectin levels,

Table 3 The amino acid composition of S. zunasi Bleeker (mean \pm SD, $n=3$ )

\begin{tabular}{llr}
\hline Amino acids & Content $^{a}(\mathrm{~g} / 100 \mathrm{~g})$ & Percentage of $\mathrm{TAA}^{c}(\%)$ \\
\hline Asx (Asp + Asn) & $1.45 \pm 0.02$ & 9.48 \\
Thr $^{b}$ & $0.68 \pm 0.01$ & 4.44 \\
Ser & $0.64 \pm 0.01$ & 4.18 \\
Glx (Glu + Gln) & $2.41 \pm 0.02$ & 15.75 \\
Gly & $1.31 \pm 0.03$ & 8.56 \\
Ala & $1.19 \pm 0.02$ & 7.77 \\
Val $^{b}$ & $0.70 \pm 0.01$ & 4.58 \\
Met $^{b}$ & $0.49 \pm 0.01$ & 3.20 \\
Trp $^{b}$ & $0.11 \pm 0.00$ & 0.72 \\
Ile & & 3.66 \\
Leu $^{b}$ & $0.56 \pm 0.01$ & 7.39 \\
Tyr $^{b}$ & $1.13 \pm 0.01$ & 3.00 \\
Phe & $0.46 \pm 0.01$ & 3.92 \\
His $^{b}$ & $0.60 \pm 0.00$ & 2.42 \\
Lys & $0.37 \pm 0.01$ & 8.50 \\
Arg & $1.30 \pm 0.02$ & 6.40 \\
Pro & $0.98 \pm 0.01$ & 6.01 \\
EAA & $0.92 \pm 0.01$ & 36.41 \\
NEAA & 5.57 & 63.59
\end{tabular}

${ }^{a}$ Values expressed as wet weight. ${ }^{b}$ Essential amino acids. ${ }^{c}$ TAA: total amino acids. 
Table 4 The elemental composition of S. zunasi Bleeker (mean $\pm S D$, $n=3$ )

\begin{tabular}{ll}
\hline Elements & Content $^{a}(\mathrm{mg} / 100 \mathrm{~g})$ \\
\hline $\mathrm{Ca}$ & $1240 \pm 0.02$ \\
$\mathrm{~K}$ & $308 \pm 0.08$ \\
$\mathrm{Na}$ & $168 \pm 0.04$ \\
$\mathrm{Mg}$ & $56.30 \pm 2.7$ \\
$\mathrm{Fe}$ & $9.48 \pm 0.05$ \\
$\mathrm{Zn}$ & $2.55 \pm 0.06$ \\
$\mathrm{Mn}$ & $0.59 \pm 0.01$ \\
$\mathrm{Cu}$ & $<0.5$ \\
${ }^{a}$ Values expressed as wet weight. & \\
\end{tabular}

and decrease markers of inflammation (high-sensitivity Creactive protein). ${ }^{46}$ Thus, $S$. zunasi Bleeker could be a promising natural source of taurine with benefits for human health.

3.2.4. Mineral contents. As shown in Table 4, eight minerals were quantified in $S$. zunasi Bleeker, including four macro minerals (Ca, K, $\mathrm{Na}$, and $\mathrm{Mg}$ ) and four trace minerals (Fe, $\mathrm{Zn}, \mathrm{Mn}$, and $\mathrm{Cu})$. Ca (1240 $\pm 0.02 \mathrm{mg} / 100 \mathrm{~g})$ was the major mineral in $S$. zunasi Bleeker, the content of which was found to be higher than that in Sardinella longiceps $(523.9 \pm 45.6 \mathrm{mg} / 100$ $\mathrm{g}),{ }^{47}$ Mullus surmeletus $\left(398.6 \pm 105.9 \mathrm{mg} \mathrm{kg}^{-1}\right)$ and Upeneus moluccensis $\left(617.4 \pm 90.5 \mathrm{mg} \mathrm{kg}^{-1}\right),{ }^{48}$ followed by $\mathrm{K}(308 \pm 0.08$ $\mathrm{mg} / 100 \mathrm{~g}), \mathrm{Na}(168 \pm 0.04 \mathrm{mg} / 100 \mathrm{~g})$ and $\mathrm{Mg}(56.30 \pm 2.7 \mathrm{mg} /$ $100 \mathrm{~g})$. Ca rich in $S$. zunasi Bleeker suggests that it could be a good choice for nutritional supplements. The analysis of microelements revealed that $S$. zunasi Bleeker possessed Fe (9.48 $\pm 0.05 \mathrm{mg} / 100 \mathrm{~g}), \mathrm{Zn}(2.55 \pm 0.06 \mathrm{mg} / 100 \mathrm{~g})$ and $\mathrm{Mn}(0.59$ $\pm 0.01 \mathrm{mg} / 100 \mathrm{~g}$ ), and the content of $\mathrm{Cu}$ was less than $0.5 \mathrm{mg} /$ $100 \mathrm{~g}$. Fe is one of the essential trace minerals that good for health, the level of Fe $(9.48 \pm 0.05 \mathrm{mg} / 100 \mathrm{~g})$ in $S$. zunasi Bleeker was much higher than that in Upeneus moluccensis $\left(7.3 \mathrm{mg} \mathrm{kg}^{-1}\right)$ and Mullus surmeletus (6.4 $\mathrm{mg} \mathrm{kg}{ }^{-1}$ ), ${ }^{48}$ indicated $S$. zunasi Bleeker may be taken as a good supplement source of Fe with healthy benefits to human. ${ }^{49}$

\subsection{Extraction, purification, and physicochemical properties of $\mathrm{H} 2$}

In this study, crude glycoprotein (H1) was obtained from $S$. zunasi Bleeker by conventional hot water extraction, alcohol precipitation and deproteinization. Crude glycoprotein was further purified through anion-exchange chromatography according to differences in the existence of ionic groups. One fraction eluted with the $0.2 \mathrm{M}$ sodium chloride solution was collected (Fig. 1a). After dialysis and concentration, it was further purified by Sephadex G-200 column, and then H2 was obtained (Fig. 1b). The physicochemical properties of $\mathrm{H} 2$ were shown in Table 5. The content of total sugar and protein were $16.27 \%$ and $34.25 \%$, respectively. The main monosaccharide existed in $\mathrm{H} 2$ were mannose and galactose. The homogeneity and average molecular weight of $\mathrm{H} 2$ were measured by HPGPC shown in Fig. 1c. The GPC curves revealed that the fraction was represented by a single, sharp peak, indicated the glycoprotein

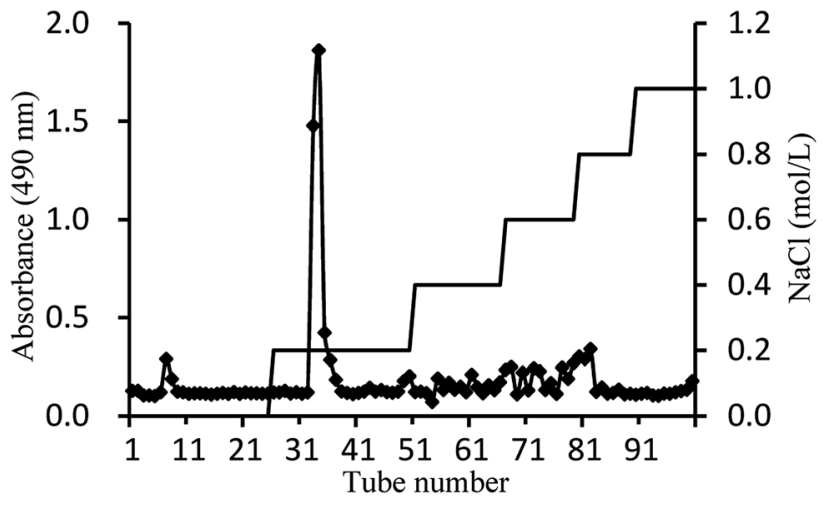

(a)

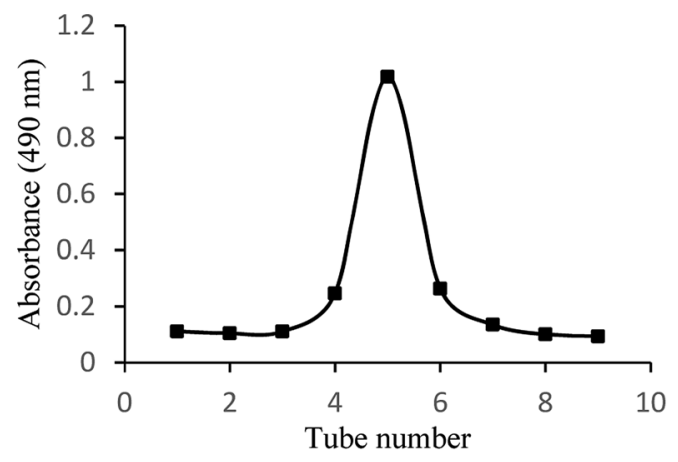

(b)

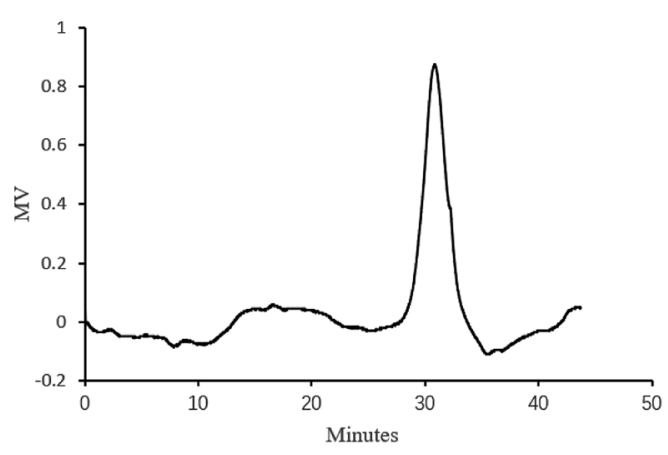

(c)

Fig. 1 Preparation and physicochemical properties of H2. (a) Elution curve on Cellulose DEAE-52 column. (b) Elution curve on G-200 column and (c) HPGPC profile of $\mathrm{H} 2$.

was relatively homogeneous in molecular weight distribution. The average molecular weight of $\mathrm{H} 2$ was calculated as $7145 \mathrm{Da}$ according to the equation of calibration curve.

Table 5 Results of composition analysis of $\mathrm{H} 2$

\begin{tabular}{llll}
\hline & & \multicolumn{2}{l}{$\begin{array}{l}\text { Sugar composition (molar } \\
\text { ratio) }\end{array}$} \\
\cline { 2 - 4 } $\begin{array}{l}\text { Total sugar } \\
\text { content }(\%)\end{array}$ & Protein content $(\%)$ & Mannose & Galactose \\
\hline 16.27 & 34.25 & 1.00 & 2.19
\end{tabular}




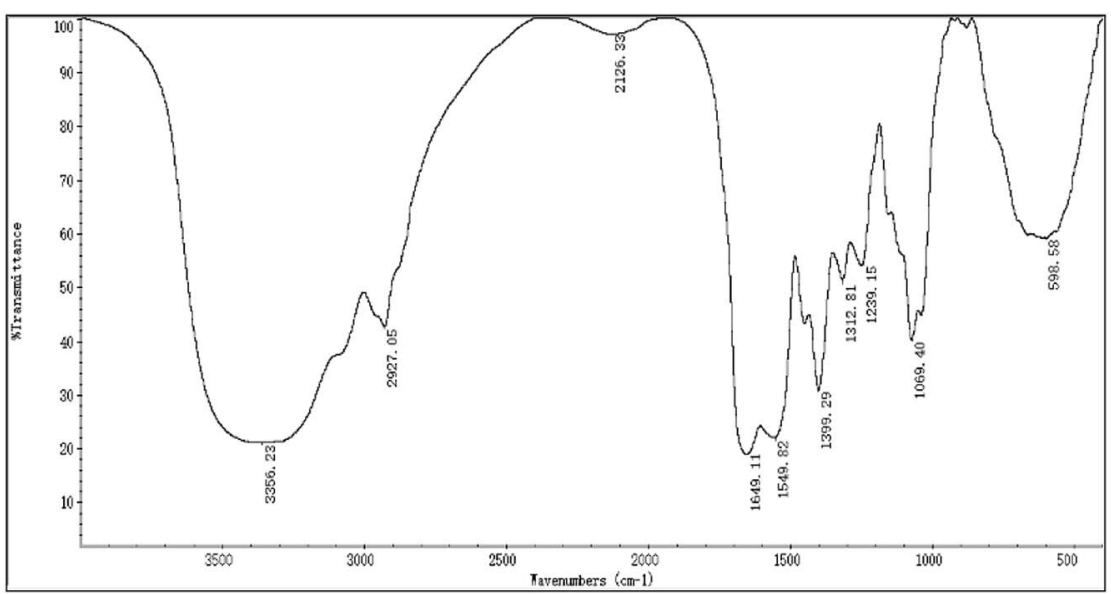

Fig. 2 The FTIR spectra of $\mathrm{H} 2$.

The FTIR spectra of $\mathrm{H} 2$ is shown in Fig. 2, most of the absorption bands could be assigned according to data obtained in previous studies. ${ }^{50-53}$ The broad stretching intense peak at $3356 \mathrm{~cm}^{-1}$ indicated the presence of hydroxyl and amino groups, ${ }^{54}$ the $2927 \mathrm{~cm}^{-1}$ region corresponded to the $\mathrm{C}-\mathrm{H}$ stretching vibration. The band at $1649 \mathrm{~cm}^{-1}$ was the $\mathrm{C}=\mathrm{O}$ stretching vibration of amide group. The absorption peak at $1399 \mathrm{~cm}^{-1}$ represented the $\mathrm{C}-\mathrm{O}-\mathrm{H}$ carboxylic acid, and the strong peak observed at $1069 \mathrm{~cm}^{-1}$ was characteristic of all sugar derivatives and hydroxyl group. ${ }^{55}$ The spectra indicated H2 was a glycoprotein.

\subsection{Immunomodulatory activity of $\mathbf{H} 2$}

3.4.1. Effects of $\mathbf{H} 2$ on RAW264.7 cells viability. To investigate the toxicity of $\mathrm{H} 2$ towards the RAW264.7 cells, their viability was evaluated by MTT assay after treatment with different $\mathrm{H} 2$ concentrations $(10,20,40,60,80,100,120$ and 140 $\mu \mathrm{g} \mathrm{mL}{ }^{-1}$ ) for $24 \mathrm{~h}$. As shown in Fig. 3, with the rise of $\mathrm{H} 2$ concentrations from $10 \mu \mathrm{g} \mathrm{mL}{ }^{-1}$ to $120 \mu \mathrm{g} \mathrm{mL}^{-1}$, the viability of RAW264.7 cells increased. At the concentrations of 10, 20 and

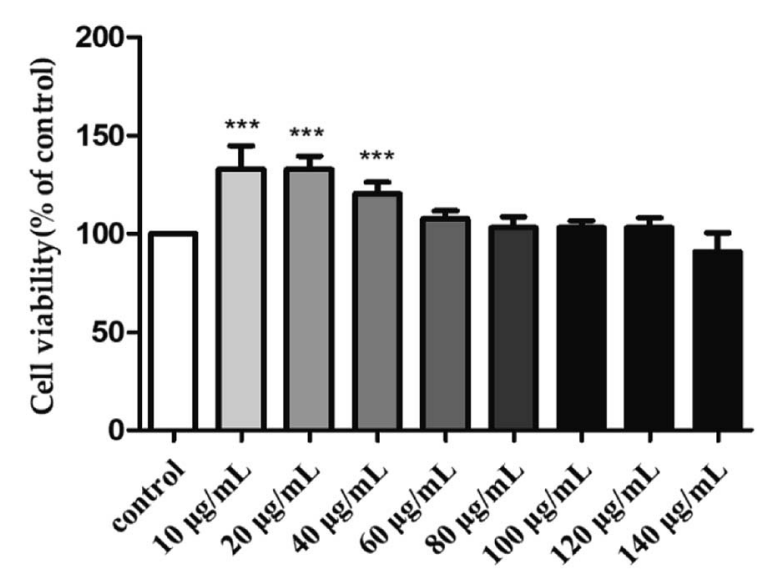

Fig. 3 Effect of $\mathrm{H} 2$ on the viability of RAW264.7 cells. $* * * P<0.001$, vs. the control group.
$40 \mu \mathrm{g} \mathrm{mL} \mathrm{m}^{-1}$, the viability rates of RAW264.7 were $132.91 \pm$ $11.85 \%, 132.71 \pm 6.88 \%$ and $120.34 \pm 5.95 \%$, respectively. The viability was not significantly $(P>0.05)$ influenced by $\mathrm{H} 2$ at the concentrations from $60 \mu \mathrm{g} \mathrm{mL}{ }^{-1}$ to $120 \mu \mathrm{g} \mathrm{mL}{ }^{-1}$, compared with control group. When the concentration of $\mathrm{H} 2$ was up to 140 $\mu \mathrm{g} \mathrm{mL} \mathrm{m}^{-1}$, the viability of RAW264.7 cells decreased. The results of present study indicated $\mathrm{H} 2$ at concentrations below $120 \mu \mathrm{g}$ $\mathrm{mL}^{-1}$ was nontoxic to RAW264.7 cells, thus allowing concentrations from $10 \mu \mathrm{g} \mathrm{mL}^{-1}$ to $120 \mu \mathrm{g} \mathrm{mL}^{-1}$ being used for further study.

3.4.2. Effects of $\mathbf{H 2}$ on phagocytic uptake. The phagocytic function of macrophages plays an important role in immune responses. ${ }^{56}$ Therefore, the effect of $\mathrm{H} 2$ on the phagocytic activities of RAW264.7 cells was examined by the uptake of neutral red. As showed in Fig. 4, H2 stimulated the phagocytic activity of RAW264.7 cells in a dose-dependent manner in the concentration ranged from $10 \mu \mathrm{g} \mathrm{mL}^{-1}$ to $120 \mu \mathrm{g} \mathrm{mL}^{-1}$ compared with the control group. The stimulatory effect of $\mathrm{H} 2$ on phagocytic activity of RAW264.7 cells did not differ significantly from that in the control group $(P>0.05)$ in the

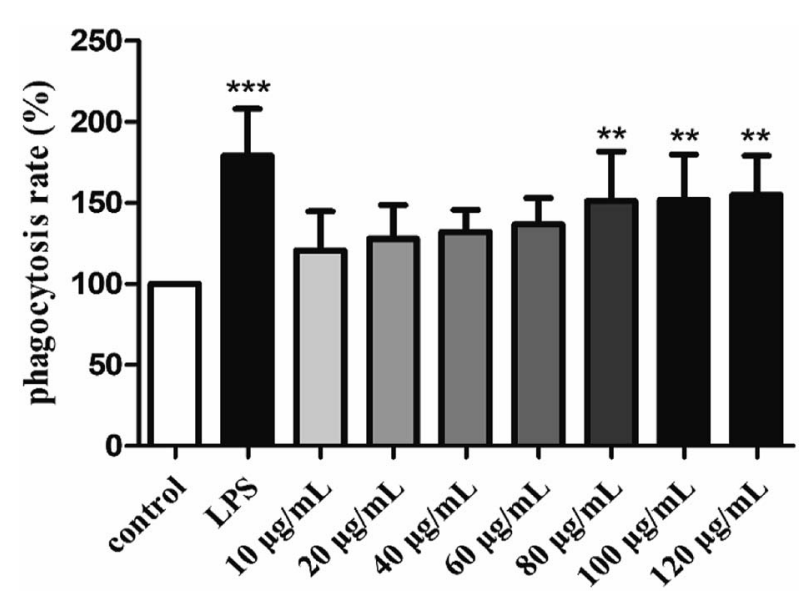

Fig. 4 Effects of $\mathrm{H} 2$ on phagocytic uptake from RAW264.7 cells. **P< $0.01, * * * P<0.001$, vs. the control group. 
concentration ranged from $10 \mu \mathrm{g} \mathrm{mL} L^{-1}$ to $60 \mu \mathrm{g} \mathrm{mL} L^{-1}$. With the concentrations of $\mathrm{H} 2$ increased, the phagocytic activity was significant $(P<0.01)$ compared with the control group, indicated that $\mathrm{H} 2$ had abilities to promote phagocytic activities of macrophages at concentrations beyond $60 \mu \mathrm{g} \mathrm{mL} L^{-1}$. However, the stimulatory effects of $\mathrm{H} 2$ on phagocytic activity were lower than that of LPS.

3.4.3. Effects of $\mathbf{H} 2$ on NO production. As a kind of important signal transduction medium, NO plays an important role in the immune system. ${ }^{57}$ Analysis of the release of NO by activated macrophages can reflect the effects of $S$. zunasi Bleeker glycoprotein on immune function. Griess assay was used to determine the effect of $\mathrm{H} 2$ on the production of a macrophageactivating factor NO of RAW264.7 cells. The release of NO caused by $\mathrm{H} 2$ were shown in Fig. 5 , the NO concentration of the culture supernatant of the RAW264.7 cells were increased by $\mathrm{H} 2$ in a dose-dependent manner from $5 \mu \mathrm{g} \mathrm{mL} \mathrm{mL}^{-1}$ to $60 \mu \mathrm{g} \mathrm{mL}^{-1}$. Furthermore, the production of NO stimulated by a high concentration $\left(60 \mu \mathrm{g} \mathrm{mL} \mathrm{m}^{-1}\right)$ of $\mathrm{H} 2$ was even more than LPStreated group.

3.4.4. Effects of $\mathrm{H} 2$ on TNF- $\alpha$ and IL-6 production. Cytokines are small molecular proteins secreted by activated monocyte-macrophages and lymphocytes. TNF- $\alpha$ and IL-6 are two important cytokines that play a role in immune response. The production of TNF- $\alpha$ (Fig. 6a) and IL-6 (Fig. 6b) were low in the control group, compared with control group, treatment with $\mathrm{H} 2$ can induce TNF- $\alpha$ and IL-6 release in RAW264.7 cells in a dose-dependent manner from $5 \mu \mathrm{g} \mathrm{mL} \mathrm{m}^{-1}$ to $60 \mu \mathrm{g} \mathrm{mL} \mathrm{m}^{-1}$. The production of TNF- $\alpha(5,10,20$ and $60 \mu \mathrm{g} \mathrm{mL} \mathrm{m}^{-1}$ ) was measured to be 5.5-fold, 8.1-fold, 15.5fold and 16.9-fold of control group. Moreover, the production of TNF- $\alpha$ induced by $\mathrm{H} 2$ at concentration of $60 \mu \mathrm{g} \mathrm{mL}^{-1}$ showed a comparative level of the LPS-treated group. The production of IL-6 induced by low concentration $\left(5 \mu \mathrm{g} \mathrm{mL} \mathrm{mL}^{-1}\right)$ of $\mathrm{H} 2$ showed no significance $(P>0.05)$ compared with control group, with the increase of $\mathrm{H} 2$ concentrations from $10 \mu \mathrm{g} \mathrm{mL} \mathrm{mL}^{-1}$ to $60 \mu \mathrm{g} \mathrm{mL} \mathrm{m}^{-1}$, production of IL-6 increased, but still less than the LPS-treated group.

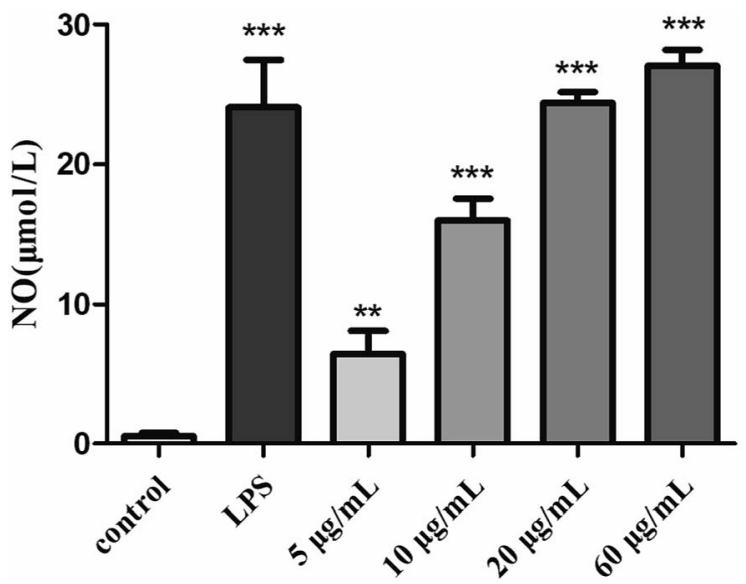

Fig. 5 Effects of $\mathrm{H} 2$ on $\mathrm{NO}$ release from RAW264.7 cells. $* * P<0.01$, $* * * P<0.001$, vs. the control group.

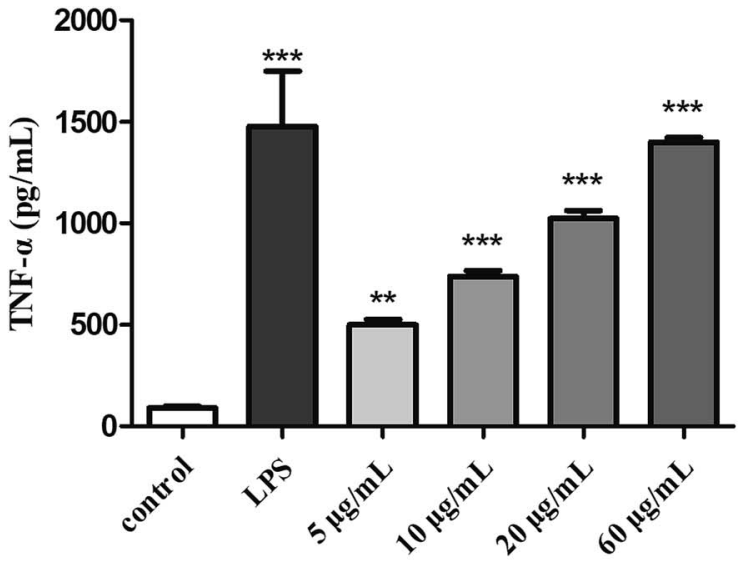

(a)

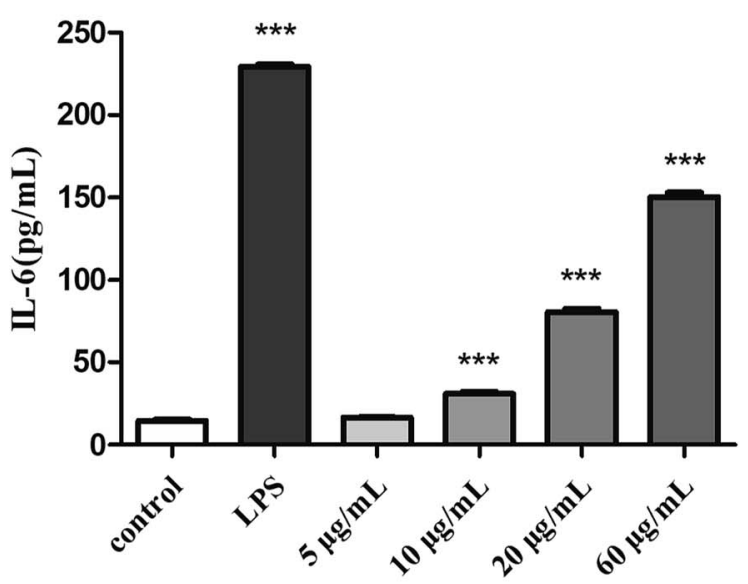

(b)

Fig. 6 Effects of $\mathrm{H} 2$ on (a) TNF- $\alpha$ and (b) IL-6 from RAW264.7 cells. $* * P<0.01, * * * P<0.001$, vs. the control group.

\section{Conclusions}

To sum up, the study revealed that $S$. zunasi Bleeker was a valuable marine fish for containing high level of protein and taurine. The amino acids and mineral composition indicated $S$. zunasi Bleeker was a good source of essential amino acids and micronutrients. Furthermore, S. zunasi Bleeker can be considered as a potential dietary source of DHA and EPA. The glycoprotein from S. zunasi Bleeker showed a significant immunostimulatory activity on RAW264.7 cells. It could not only promote cell proliferation and phagocytosis, but also promote inflammatory cytokines secretion. Thus, S. zunasi Bleeker can be considered as a nutritional supplement with a potential immunostimulatory property.

\section{Conflicts of interest}

There are no conflicts to declare. 


\section{Acknowledgements}

This research was funded by Science and Technology Planning Project of Guangdong Province, Guangzhou Planned Program in Science and Technology, Program of Department of Ocean and Fisheries of Guangdong Province, Natural Science Foundation of Guangdong, Guangdong Provincial Key Laboratory of Applied Botany, South China Botanical Garden, Chinese Academy of Sciences, Finance Special Project of Zhanjiang City, Natural Science Foundation of Guangdong, grant number 2017A020217002, 201803020003, GDME2018C014, 2016A030313151, AB2018004, 2018A01044 and 2018A0303070018.

\section{Notes and references}

1 C. E. Fernandes, M. A. D. Vasconcelos, M. D. Ribeiro, L. A. Sarubbo, S. A. C. Andrade and A. B. de Melo, Food Chem., 2014, 160, 67-71.

2 A. K. M. Bhuiyan, W. M. N. Ratnayake and R. G. Ackman, J. Food Compos. Anal., 1993, 6, 172-184.

3 S. A. Otitologbon, E. B. Agbaji, O. A. Peters and S. J. Oniye, J. Sci. Food Agric., 1997, 75, 312-314.

4 D. Kromhout, E. B. Bosschieter and C. de Lezenne Coulander, N. Engl. J. Med., 1985, 312, 1205-1209.

5 D. Kromhout, E. J. Feskens and C. H. Bowles, Int. J. Epidemiol., 1995, 24, 340-345.

6 S. E. Norell, A. Ahlbom, M. Feychting and N. L. Pedersen, Br. Med. J., 1986, 293, 426.

7 T. A. Dolecek and G. Granditis, World Rev. Nutr. Diet., 1991, 66, 205-216.

8 A. J. McMichael and C. D. Butler, Am. J. Prev. Med., 2005, 29, 322-323.

9 R. M. Krauss, R. H. Eckel, B. Howard, L. J. Appel, S. R. Daniels, R. J. Deckelbaum, J. W. J. Erdman, P. KrisEtherton, I. J. Goldberg, T. A. Kotchen, A. H. Lichtenstein, W. E. Mitch, R. Mullis, K. Robinson, J. Wylie-Rosett, S. St. Jeor, J. Suttie, D. L. Tribble and T. L. Bazzarre, Circulation, 2000, 102, 2284-2299.

10 T. M. Tengku-Rozaina, W. S. Jeng and M. A. Amiza, J. Aquat. Food Prod. Technol., 2018, 27, 667-679.

11 F. S. Hamdan and N. M. Sarbon, Int. Food Res. J., 2019, 26, 133-140.

12 A. Taheri, N. Sarhaddi, G. A. Bakhshizadeh and S. Sharifian, Iran. J. Fish. Sci., 2017, 16, 1312-1324.

13 O. M. Bahurmiz, F. Adzitey and W. K. Ng, Int. Food Res. J., 2017, 24, 2387-2393.

14 N. Souissi, A. Bougatef, Y. Triki-Ellouz and M. Nasri, Food Technol. Biotechnol., 2007, 45, 187-194.

15 A. Barkia, A. Bougatef, H. Ben Khaled and M. Nasri, J. Food Biochem., 2010, 34, 303-320.

16 R. S. C. Som and C. K. Radhakrishnan, Indian J. Geo-Mar. Sci., 2011, 40, 710-716.

17 R. S. C. Som, P. Pillai, S. Lekshmi and C. K. Radhakrishnan, Indian J. Geo-Mar. Sci., 2017, 46, 290-294.

18 Z. Kamoun, A. S. Kamoun, A. Bougatef, R. M. Kharrat, H. Youssfi, T. Boudawara, M. Chakroun, M. Nasri and N. Zeghal, Environ. Sci. Pollut. Res., 2017, 24, 1432-1441.
19 I. Jemil, O. Abdelhedi, R. Nasri, L. Mora, R. Marrekchi, K. Jamoussi, A. ElFeki, M. Hajji, F. Toldra and M. Nasri, Life Sci., 2017, 176, 54-66.

20 B. E. C. Ziani, W. Rached, K. Bachari, M. J. Alves, R. C. Calhelha, L. Barros and I. C. F. R. Ferreira, J. Funct. Foods, 2019, 53, 237-247.

21 M. E. Orqueda, M. Rivas, I. C. Zampini, M. R. Alberto, S. Torres, S. Cuello, J. Sayago, S. Thomas-Valdes, F. Jimenez-Aspee, G. Schmeda-Hirschmann and M. I. Isla, Food Chem., 2017, 216, 70-79.

22 G. P. Li, A. J. Sinclair and D. Li, J. Agric. Food Chem., 2011, 59, 1871-1881.

23 L. B. Wang, F. C. Liu, A. X. Wang, Z. Y. Yu, Y. Q. Xu and Y. Yang, Food Hydrocolloids, 2017, 66, 357-364.

24 T. Mosmann, J. Immunol. Methods, 1983, 65, 55-63.

25 R. M. Martinez, D. D. B. Guimaraes, C. R. Berniz, J. P. de Abreu, A. P. M. da Rocha, R. S. de Moura, A. C. Resende and A. J. Teodoro, Foods, 2018, 7, 178.

26 X. Liu, J. H. Xie, S. Jia, L. X. Huang, Z. J. Wang, C. Li and M. Y. Xie, Int. J. Biol. Macromol., 2017, 98, 576-581.

27 Q. Yu, S. P. Nie, W. J. Li, W. Y. Zheng, P. F. Yin, D. M. Gong and M. Y. Xie, Phytother. Res., 2017, 27, 186-191.

28 D. Kocatepe and H. Turan, Lipids, 2012, 47, 635-641.

29 P. Puwastien, K. Judprasong, E. Kettwan, K. Vasanachitt, Y. Nakngamanong and L. Bhattacharjee, J. Food Compos. Anal., 1999, 12, 9-16.

30 S. J. Iverson, K. J. Frost and S. L. C. Lang, Mar. Ecol.: Prog. Ser., 2002, 241, 161-181.

31 M. Zaman, M. N. Naser, A. T. M. Abdullah and N. Khan, Bangladesh J. Zool., 2014, 42, 251-259.

32 A. D. Diwan, H. G. Hingorani and N. Chandrasekhram Naidu, Bull. Environm. Contain. Toxicol., 1979, 21, 269-272.

33 R. D. Santos, A. C. M. Gagliardi and H. T. Xavier, Arq. Bras. Cardiol., 2013, 100, 1-40.

34 K. Imura and A. Okada, Nat. Conserv., 1998, 14, 143-148.

35 A. M. M. Jais, R. McCulloch and K. Croft, Gen. Pharmacol., 1994, 25, 947-950.

36 G. Y. Wu, Adv. Nutr., 2010, 1, 31-37.

37 O. O. Oluwaniyi, O. O. Dosumu and G. V. Awolola, Food Chem., 2010, 123, 1000-1006.

38 T. R. Gormley, T. Neumann, J. D. Fagan and N. P. Brunton, Eur. Food Res. Technol., 2007, 225, 837-842.

39 M. Imae, T. Asano and S. Murakami, Amino Acids, 2014, 46, 81-88.

40 S. Murakami, Amino Acids, 2014, 46, 73-80.

41 Y. Yamori, T. Taguchi, A. Hamada, K. Kunimasa, H. Mori and M. Mori, J. Biomed. Sci., 2010, 17, S6.

42 Y. Yamori, T. Taguchi, H. Mori and M. Mori, J. Biomed. Sci., 2010, 17, S21.

43 M. Zhang, L. F. Bi, J. H. Fang, X. L. Su, G. L. Da, T. Kuwamori and S. Kagamimori, Amino Acids, 2004, 26, 267-271.

44 E. O. Elvevoll, K. E. Eilertsen, J. Brox, B. T. Dragnes, P. Falkenberg, J. O. Olsen, B. Kirkhus, A. Lamglait and B. Osterud, Atherosclerosis, 2008, 200, 396-402.

45 S. Murakami, Life Sci., 2017, 186, 80-86.

46 F. T. Rosa, E. C. Freitas, R. Deminice, A. A. Jordao and J. S. Marchini, Eur. J. Nutr., 2014, 53, 823-830. 
47 B. P. Mohanty, T. V. Sankar, S. Ganguly, A. Mahanty, R. Anandan, K. Chakraborty, B. N. Paul, D. Sarma, J. S. Dayal, S. Mathew, K. K. Asha, T. Mitra, D. Karunakaran, S. Chanda, N. Shahi, P. Das, P. Das, M. S. Akhtar, P. Vijayagopal and N. Sridhar, Biol. Trace Elem. Res., 2016, 174, 448-458.

48 A. Oksuz, A. Ozyilmaz and S. Kuver, Turk. J. Fish. Aquat. Sci., 2011, 11, 69-75.

49 F. Camara, M. A. Amaro, R. Barbera and G. Clemente, Food Chem., 2005, 92, 481-489.

50 L. Gong, H. Zhang, Y. G. Niu, L. Chen, J. Liu, S. Alaxi, P. P. Shang, W. J. Yu and L. L. Yu, J. Agric. Food Chem., 2015, 63, 569-577.

51 W. Li, X. D. Xia, W. Z. Tang, J. Ji, X. Rui, X. H. Chen, M. Jiang, J. Z. Zhou, Q. Q. Zhang and M. S. Dong, J. Agric. Food Chem., 2015, 63, 3454-3463.
52 A. Ebrahiminezhad, F. Moeeni, S. M. Taghizadeh, M. Seifan, C. Bautista, D. Novin, Y. Ghasemi and A. Berenjian, Foods, 2019, 8, 88.

53 G. T. Chen, Y. X. Fu, W. J. Yang, Q. H. Hu and L. Y. Zhao, Int. J. Biol. Macromol., 2018, 107, 2150-2156.

54 A. E. Abd El-Salam, D. Abd-El-Haleem, A. S. Youssef, S. Zaki, G. Abu-Elreesh and S. A. El-Assar, Braz. J. Biol., 2017, 15, 335344.

55 S. Busi, S. Karuganti, J. Rajkumari, P. Paramanandham and S. Pattnaik, Water Environ. J., 2017, 31, 97-104.

56 Y. Yu, M. Y. Shen, Z. J. Wang, Y. X. Wang, M. Y. Xie and J. H. Xie, Carbohydr. Polym., 2017, 174, 669-676.

57 W. X. Chen, W. Y. Zhang, W. B. Shen and K. C. Wang, Cell. Immunol., 2010, 262, 69-74. 